\title{
Resistance and the Black freedom movement: Reflections on White's Freedom Farmers
}

Introduction by Garrett Graddy-Lovelace, American University

Reflections by:

Priscilla McCutcheon, University of Kentucky

Ashanté M. Reese, University of Maryland, Baltimore County

Angela Babb, Indiana University

Jonathan C. Hall, West Virginia University

Eric Sarmiento, Texas State University

Bradley Wilson, West Virginia University

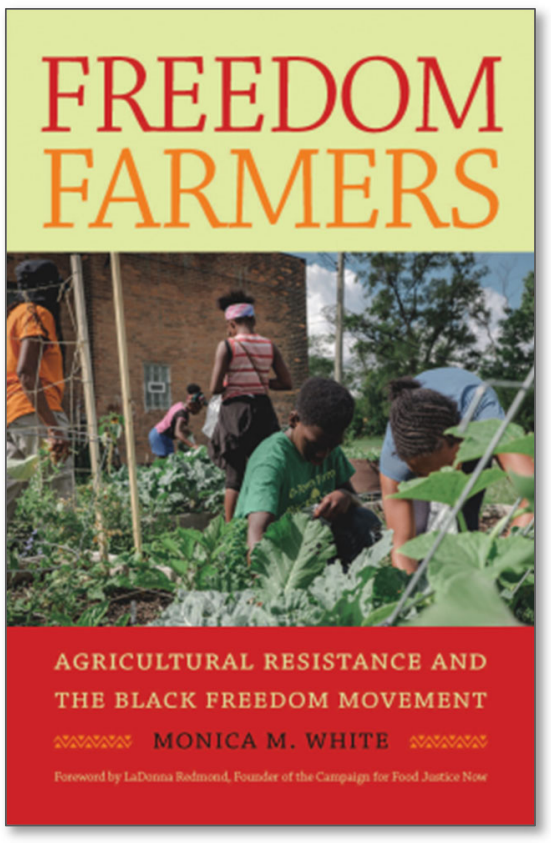

Reviews of Freedom Farmers: Agricultural Resistance and the Black Freedom Movement, by Monica M. White. (2019). University of North Carolina

Press. Available as hardcover and ebook; 208 pages. Publisher's website: https://uncpress.org/book/9781469643694/freedom-farmers/

Submitted September 5, 2019 / Published online March 6, 2020

Citation: Graddy-Lovelace, G., McCutcheon, P., Reese, A. M., Babb, A., Hall, J. C., Sarmiento, E., \& Wilson, B. (2020).

Resistance and the Black freedom movement: Reflections on White's Freedom Farmers [Book review]. Journal of Agriculture,

Food Systems, and Community Development, 9(2), 287-295. https://doi.org/10.5304/jafscd.2020.092.020

Copyright (C) 2020 by the Authors. Published by the Lyson Center for Civic Agriculture and Food Systems. Open access under CC-BY license.

\section{Introduction}

Garrett Graddy-Lovelace, American University*

Landmark: 1. An object or feature of a landscape ... that is easily seen and recognized from a distance, especially one that enables someone to establish their location. Synonyms: mark, indicator, guiding light, signal, beacon, lodestar.

2. An event or discovery marking an important stage or turning point in something. Synonyms: milestone, watershed ... major achievement. (“Landmark," n.d., para. 1 \& 4)

* Dr. Graddy-Lovelace coordinated this set of reflections. She is Associate Professor, School of International Service, American University; graddy@american.edu
Dr. Monica White's Freedom Farmers: Agricultural Resistance and the Black Freedom Movement stands literally as a landmark, ushering in a new era of community-based scholarship with and for agrarian justice. From here on out, scholars, activists, practitioners have a lodestar from which to research, practice, and advocate for food, farm, and racial justice: Dr. White's framework of "collective agency and community resilience" (CACR). Food studies scholars from across and beyond academic disciplines are in strong consensus as to the importance of this pivotal 
book - a manuscript that draws upon and advances rural sociology, history, agri-food studies, Black history, cooperative economics, and more. In this set of reflections on Freedom Farmers, McCutcheon lauds how the work is a "love letter" to past, present, and future Black farmers, and the powerful pedagogical potential of such celebration. Reese recounts how the book excavates the erased histories of Black women leaders and farmers, showing us how to "re/see the world" through this powerful lens. Babb calls the text a gift that "flips the script" to provide informative and inspirational narratives of food justice and food sovereignty in action. Hall commends how the book "pushes us to participate in the remaking of our communities with honesty, resilience, solidarity, and love." Sarmiento notes how, even as the book critiques structural racism, it offers a generous, affirmative vision of resistance and agency. Wilson concurs that the book opens radical possibilities for hope, particularly in the classroom. I would also point readers to Cynthia Greenlee's (2018) Civil Eats interview with Dr. White, which highlights how the book sheds light on the overlooked role of Black farmers in the Civil Rights movement, resurgence of Black agriculture and scholarship on it, and the ongoing necessity of affirming collective agency in the fight against racism at large.

This book serves, temporally, as a turning point in community-based scholarship: what comes after benefits from its milestone clarity and content and commitment. Spatially, it stands as a beacon: scholars from across and beyond the disciplines can better find each other in relation to this book's central messages. I research geographies and political ecologies of agrobiodiversity — realms rich with collective agency and community resilience. Dr. White's framework helps me see this-and recount it. It also helps me connect with other scholar-activists discerning these truths in their respective areas of study and movement-building.

Dr. White self-describes as a garden griot. As the Black Farmers' Historian, she learns and recounts African-diaspora agricultural knowledges across the southern and rural United States-so as to pass it along. As in the West African griot tradition, she braids histories and geographies into a narrative of what the youth Need to Know-what is worth remembering and transmitting to the next generation. She has meticulously recovered the valuable, systemically overlooked stories of Black farming resistance- the practices, traditions, and efforts. Even though white supremacy blocked thembecause white supremacy blocked them-it is all the more important to remember and remind each other of these crucial, courageous, creative Blackled agricultural projects. Here, they are researched, gathered, and written up with clarity and careready to be read, learned, and passed further along. Ready to inspire a whole new generation of Blackled agrarian liberation. This book promises to go far, spatially and temporally — and it already has. Dr. White has been invited to speak on the book's findings across the country. A wave of students are picking up and applying the CACR framework, which already serves as a clarifying theoretical beacon.

The methods section begins with Sankofa, "studying the past to understand the present, and from that, to forge a future of our own making" (p. 19). In studying this largely as-of-yet-unwritten past, Professor White finds and transmits to us examples of CACR, and in this she summarizes that which came before and that which will lead us forward. In these stories, we learn that resistance is necessarily composed of commons. We see that freedom from oppression necessitates layers of praxis, prefigurative politics, and economic autonomy. We see glimpses of the long, erased history of Black women leadership in agriculture and food sovereignty.

This analysis-so deceptively simple, yet so critical-helps move us beyond the farce of individualized agency and resilience, illusions laden with patriarchy and racism, and yet undergirding academia — and academic analysis. Food studies, among other disciplines, has a milestone here. Scholarship from here on out can reference this book and build upon its insights moving forward. Community-level work requires community-level thinking and doing. Liberation requires economic autonomy along with food and land sovereignty, but this unfolds as a process: iterative, historical, ancestral. Freedom emerges not as an object, but as a practice- - thwarted but ultimately unstoppable. And land, agrarian land, 
allows the space and place to prefigure and thus practice freedom. In short: this book, a landmark of community-based scholarship, connects us and guides us forward.

\section{References}

Greenlee, C. (2018, December 20). 'Freedom Farmers' tells the history of Black farmers uniting against racism. Civil Eats.

Retrieved from

https://civileats.com/2018/12/20/freedom-farmers-tells-the-history-of-black-farmers-uniting-against-racism/

Landmark. (n.d.). In Lexico. Retrieved March 4, 2020, from https://www.lexico.com/definition/landmark

\section{Reflection \#1}

\section{A "love letter" to Black farmers}

\section{Priscilla McCutcheon, University of Kentucky*}

There are times when writing is difficult, when the words are hard to retrieve, and the emotion is palpable. But to me the product feels like love, never easy but worth it. This book is a love letter. (White, 2018, p. 26).

Freedom Farmers strikes an emotional chord with me that few books do. Much of this emotion stems from Dr. Monica White's commitment to writing a "love letter." The intentionality that White must have had to make sure that love is evident in each word reflects how brilliant and remarkable her work is. In my estimation, the love that White has for the land, food, Black people, and Black communities is most evident in the nuance and attention to detail in this groundbreaking work. For these brief remarks, I focus on one example of such detail and how its inclusion reflects a commitment to expanding how we understand Black people's history and contributions to economic and cooperative development.

In Freedom Farmers, White meticulously examines cooperative development among Black people through historical examples like Fannie Lou Hamer's Freedom Farms and present-day examples like the Detroit Black Community Food Security Network. White details how DuBois's theories on "economic co-operations" (p. 53) guides her think-

* Priscilla McCutcheon, Assistant Professor, Department of Geography, University of Kentucky, priscilla.mccutcheon@uky.edu ing and theorizing on cooperative development. DuBois understands cooperative development through institutions, like the black church, that Black people have developed and maintained in the midst of oppressive conditions. White says about DuBois's reading of black churches that they:

served as a critical pathway to political organizations that led the way to economic self-determination ... the pooling together of the tithes and offerings functioned as a form of economic cooperation that paved the way to beneficial and burial societies and that provided services for those who suffered from extreme conditions of poverty, especially under the oppressive conditions of plantation agriculture. (pp. 53-54)

The example and explanation of black churches as cooperative development might be a minor point to some, but it is an example of why Freedom Farmers is a love letter to Black people. White highlights the nuances of Black life that are lost on many by citing and exploring institutions that are rarely given proper treatment. White explains that these institutions are not accidentally impactful, but reflect Black people's commitment, passion, and planning. As food studies scholars and practitioners, recognizing nuance in institutions like the Black church forces us to readjust how we look at spaces we oftentimes organize in. Simply, the 
buildings or adjacent plots that we enact our food justice initiatives on are not passive sites. Instead, the plans for effective organizing already exist in these structures that have planned, built, and survived since their inception.

Through Freedom Farmers, White celebrates the nuance of Black people and Black communities in ways that are awe-inspiring. As a Black academic, it is rare that I see Black history in all of its beauty and complexities reflected so clearly on the pages of a monograph. For her love letter, I am grateful.

\title{
Reflection \#2 Sankofa
}

\author{
Ashanté Reese, University of Maryland, Baltimore County*
}

In Freedom Farmers, Dr. Monica White writes, "in researching this book, I have sought to embody the African principle of sankofa: studying the past to understand the present, and from that, to forge a future of our making" (White, 2018, p. 19). In the embodying of this principle, however, she does more than study the past to understand the present. Freedom Farmers evokes two other meanings of sankofa: to go back and get it, and the literal translation, "it is not taboo to fetch what is at risk of being left behind" (Berea College, n.d., para. 1). Freedom Farmers is a rigorously researched and beautifully written book that reorients us to see how farming, food, race, and economics intersect, and what Black leaders across time and space have done with those intersections. When I am talking to audiences about our food system, many mention cooperatives as a solution and point to recently formed cooperatives, mostly in California. The South is rarely, if ever, mentioned. In its effort to study the past to understand the present, Freedom Farmers offers a model of cooperatives with Black farmers at the center.

One might ask: how does this shape or alter our understanding of cooperative models? White makes it clear that farmers were not solely focused on production or providing food. Instead, she shows that their understanding of economic and food justice were deeply intertwined with questions of racial justice and, to some extent, gender justice. In doing so, White provides a radically different starting point from which to theorize "food justice," powerfully demonstrating that organizing around food has always been or had the potential to be about more than consumption.

In Wayward Lives, Beautiful Experiments, Saidiya Hartman (2019) take social scientists to task for how we have seen or not seen Black and poor people, and how we have often missed the beautiful, intricate lives they make. She is asking us to look for the places and ways that Black people, and women and girls especially, make spaces akin to freedom. Freedom Farmers does that. In this book, in a sankofa moment, it asks us to do more than remember. It pushes us to gather up pieces of history, stitch those pieces together, and re/see the world through a lens through which Black farmers, leaders, and activists are assets in the food world and not just problems to be solved.

\section{References}

Berea College. (n.d.). The power of sankofa: Know history. Retrieved September 2019 from the Carter G. Woodson Center, Berea College, website: https://www.berea.edu/cgwc/the-power-of-sankofa/

Hartman, S. (2019). Wayward lives, beautiful experiments. New York: W. W. Norton.

* Ashanté Reese, Assistant Professor, University of Maryland,

Baltimore County, areese@umbc.edu 


\title{
Reflection \#3
}

\section{A gift of celebration}

\author{
Angela Babb, Indiana University*
}

Freedom Farmers is a generous gift, a labor of love, and a beautiful demonstration of scholar activism from the wonderful Dr. Monica White. In this indispensable addition to the food studies canon, White mobilizes stories of power and resistance at the site of agriculture and resituates Black farmers in our historical imaginations. She breaks through the dominant narratives of exploitation and oppression with the narratives of courage and ingenuity that celebrate Black farmers of the past and will inspire generations of Black farmers to come.

Although the traumatic realities of our food system must be exposed and rectified, the stories of resistance and survival are critical to the healing process. Freedom Farmers contributes the stories we need to remain hopeful in the face of persistent trauma. White exposes the oppression while also emphasizing the resourcefulness of Black farmers during centuries of discrimination. For instance, White relieves and inspires us with the stories of Fannie Lou Hamer's courageous testimony before Congress, her use of spirituals to calm rioting activists, and her creation of the Freedom Farm Collective, an institution that provided housing, employment, education, healthcare, and food to Black communities in the U.S. South. Mentors and teachers can be excited to assign this book and likely to evoke the emotional paralysis often experienced by students learning about the food system. Freedom Farmers provides not only inspirational narratives of food justice but also a theoretical framework for the actualization of food sovereignty.

To this end, White demonstrates scholar activism and, in particular, how social scientists can use their skills and resources to uncover obscured truths and disrupt partial-yet-dominant narratives. By unearthing and sharing the triumphs of historically black colleges and universities, the Freedom Farm Collective and the Detroit Black Community Food Security Network, White exhibits the scholarship needed to amplify the food justice movement and to move the fields of social geography and agrarian studies forward. Moreover, White's theoretical framework of collective agency and community resilience (CACR) provides a strategy for researching power and the transformative potential of initiatives emerging from across the contemporary food movement.

Perhaps most importantly, Freedom Farmers is a celebration of Black farmers and of the power, autonomy, and community that comes with growing food together. We need this book right now, as farms decline in number and increasingly fewer of our youth plan to steward the land. The continuous devaluation of farming and agrarian livelihoods throughout our cultural, political, and educational institutions is actively discouraging the next generation of farmers and thus directly threatening the viability of American agriculture. White flips the script, so to speak, to celebrate the ways that farmers are courageous, noble, and central to community resilience. In this way, Freedom Farmers is a gift to past, existing, and prospective farmers, as well as the general population that relies on someone else to grow their food. Freedom Farmers is a milestone for social geographers, critical food scholars, and farmers alike, and it is truly a gift to us all, regardless of race, religion, income, or occupation.

\footnotetext{
* Angela Babb, Postdoctoral Fellow, Ostrom Workshop, Indiana University; ababb@iu.edu
} 


\section{Reflection \#4 A reflection on Freedom Farmers}

\author{
Jonathan C. Hall, West Virginia University*
}

I immensely enjoyed and learned a tremendous amount from Dr. Monica M. White's book, Freedom Farmers: Agricultural Resistance and the Black. Freedom Movement. Dr. White frames this ongoing movement brilliantly from its beginnings in the postemancipation South, to contemporary movements that spring from, support, and empower Black communities in urban areas like Detroit, Michigan. One of the most meaningful elements of this work for me is how Dr. White positions the work of Black scholars, activists, and community members as always having existed at the foundation of progressive agriculture. Whether it is George Washington Carver's often overlooked contributions to the local, community-based agricultural movement, or the concept and practice of food cooperatives engineered by Fanny Lou Hamer, Freedom Farmers shares an important and overlooked narrative that is largely absent from mainstream progressive food discourse.

An additional, important narrative woven throughout this book is the links between land ownership, food sovereignty, and freedom from oppression. I was particularly struck by how clearly Fanny Lou Hamer articulates the tactics of white supremacy to maintain control over Black people, through land disenfranchisement and starvation, and how she leads others to organize around nullifying these tactics through collective agency and community resilience. As Dr. White points out, reviews and analyses of the civil rights movement often omit the importance of Black farmers and agriculture in "feeding the movement" so that resistance could be sustained, and so that structural change within the white power structure could occur. That struggle continues today through Dr. White's analysis of the Detroit Black Community Food Security Network and this northern urban movement's roots in the Black agricultural traditions of the South. As is the case with modern-day structural white supremacy, structural oppression is maintained not so much through direct and obvious forms of violence against Black bodies, but through more indirect acts like divestment in Black communities. Freedom Farmers helps us understand this structural oppression throughout the course of American history. Despite this treachery, Dr. White amplifies a common thread of Black freedom struggle, outlining the process through which Black Detroit residents organize to persist through food sovereignty and land reclamation.

In the wake of this brilliant work, I am left wondering about the conversation between Black agricultural traditions and the ongoing struggle of Native/Indigenous people's sovereignty within the United States. Dr. White raises the profile of the ongoing work of Black people within this settler colonial state that I believe leads the reader into more broad moral and practical questions of land ownership, sovereignty, and healing among people who have and still endure systemic injustice. In addition to teaching readers about a history we all live but may misunderstand, I think Freedom Farmers pushes us to participate in the remaking of our communities with honesty, resilience, solidarity, and love. I am so thankful for this work and for Dr. White's powerful voice within and outside of the academy.

\footnotetext{
* Jonathan C. Hall, Assistant Professor of Geography, West
} Virginia University; Jonathan.Hall@,mail.wvu.edu 


\title{
Reflection \#5 \\ Narratives of power, politics, and resistance
}

\author{
Eric Sarmiento, Texas State University*
}

Monica White's beautifully written account of Black agrarian and urban collectivist movements takes a significant step toward filling the void of writing about non-white food initiatives in 'alternative food' scholarship. The book's historical accounts of rural solidarity initiatives, such as the Freedom Farm Cooperative and the North Bolivar County Farm Cooperative, and its analysis of more contemporary community organizing through urban gardening in Detroit, are important not solely because they bring people of color into the story of remaking food systems along more just and sustainable lines (although this is a crucial contribution in its own right). These narratives also present understandings of power, politics, and resistance that differ in radical ways from those found in much critical food scholarship.

In place of a vision of totalizing, unified power structures (whether capitalism, white supremacy, global agribusiness, or neoliberal subjectivity) that in many critical accounts inevitably lead experiments in more just and sustainable food systems to co-optation, classed and racialized exclusivity, and failure, White's central theoretical construct-collective agency and community resilience (CACR) seems to present a more pragmatist ontology of power and political action. Organizing each of her accounts around this concept, she tends to briefly acknowledge the structural forces from which these resistance movements emerged, and then move on to focus on the laborious and meticulous work involved in assembling collectivities that maintain livelihoods while stewarding land and building communities that can withstand and overcome structural racist violence and class oppression. Cooperative land ownership and democratic control, in all of their complexity and messiness, are at the heart of these movements, as they provide the basis for collective self-sufficiency and political economic power. Formal and vernacular knowledges about food production are shown as crucial components of assembling power and solidarity in these sites, and White details how the farsighted and sophisticated participants in these movements attended to essentials such as education, health care, child care, and so on. Following such a pragmatist approach, White is able to walk a line in her work between critique and creation: dominant power relations are neither ignored nor reified, and the impressive power and scope of Black agrarian socio-ecological experimentation are made visible in ways that have been almost entirely absent in critical food scholarship.

Moreover, White's subjects, while clearly working in opposition to oppressive structural conditions, are shown to eschew the dark allure of resentment, a politics that is so often corrosive for all involved. In Detroit, Sunflower County, and Mound Bayou, White portrays people primarily working for better worlds rather than being preoccupied with working against the worlds that they know all too well must be eclipsed in order for more just and sustainable lives to be possible for all. This affirming and active stance reveals the true power animating the resistance movements portrayed in the book, and indeed is also expressed in the tone of White's prose: in its moments of critique, the book always remains generous, and it is suffused throughout with love for its subjects and for the broader project of creating food systems and communities that propagate well-being for people and the more-than-human world.

\footnotetext{
* Eric Sarmiento, Assistant Professor, Department of

Geography, Texas State University; ers89@txstate.edu
} 


\title{
Reflection \#6 \\ Historicizing radical Black farming as creative, expansive self-actualization
}

\author{
Bradley Wilson, West Virginia University*
}

In her essay "Radical Black Subjectivity," bell hooks laid down a challenging question that resonates for teachers and scholars of agri-food movements: "How do we create an oppositional worldview, a consciousness, an identity, a standpoint that exists not only as that struggle which opposes dehumanization but as that movement which enables creative, expansive self-actualization?" (2014, p. 15). Dr. Monica White's new book, Freedom Farmers: Agricultural Resistance and the Black. Freedom Movement, answers this question. Dr. White centers our attention on the powerful history of cooperative organizing by black farmers, from rural Mississippi in the 1960s through Detroit in the present. Dr. White not only responds to bell hooks' question with a historically rich account of black agricultural resistance and cooperation in the U.S. South, but also advances a novel theory of action-collective agency and community resilience (CACR) - that seeks to explain the creative, expansive self-actualization of black communities in the face of oppression. As she explains, black agricultural cooperative organizing was and is a means of community development and a pathway to "practice freedom" within "extreme conditions of financial, social and political oppression" (White, 2018, p. 5).

With Freedom Farmers, Dr. White has given the agri-food justice movement and critical educators everywhere a precious gift. I first encountered Dr. Monica White's written work in 2017 as I was preparing a fall seminar on food justice at West Virginia University (WVU). Searching for a new means of introducing students to the history, geography, and theory of agri-food movements in the United States, particularly the neglected regions of

\footnotetext{
* Bradley Wilson, Associate Professor of Geography, and Director, Center for Resilient Communities, West Virginia University; Bradley.Wilson@mail.wvu.edu
}

the U.S. South and Appalachia where I teach, I stumbled upon "“A Pig and a Garden': Fannie Lou Hamer and the Freedom Farms Cooperative" in the journal Food and Foodways, which was published in a different form as Chapter 2 of Freedom Farmers. So pivotal were the history and argument she put forward, so eloquent the prose, that I asked my students to read it with me before I even handed out the syllabus on the first day. We then watched a film on Fannie Lou Hamer and the civil rights movement. It was, without a doubt, one of the most moving learning moments I have ever experienced in a seminar room. Dr. White had shed light on Ms. Hamer-hailed as a civil rights crusadernow also as a visionary, farmer, cooperativist, and food justice activist.

Reframing Ms. Hamer's legacy and that of black farmers across the South, Dr. White launched us on a different genesis story for the agri-food justice movement, one rooted in the struggle for black freedom in the U.S. South. Now, with additional histories of the North Bolivar County Farm Cooperative, the Federation of Southern Cooperatives, and the Detroit Black Food Security Network, she extends these insights and accounts of collective agency and community resilience further.

In fall 2018, my staff in the WVU Food Justice Lab read Freedom Farmers, and I had the pleasure of engaging the full book with 14 students in our Appalachian Food Justice Institute in West Virginia last spring. The power of this text to educate, coalesce, and deepen our commitment to agri-food justice through her conceptualization of commons as praxis, prefigurative politics, and economic autonomy was powerful. I anticipate this book will become core reading in food and agrarian studies, and I urge my fellow teachers and researchers to center this text in their courses and build syllabi around it to further consider the standard-bearing 
Journal of Agriculture, Food Systems, and Community Development ISSN: 2152-0801 online

https://www.foodsystemsjournal.org

contributions of black farmers to U.S. agriculture, cooperativism, community food security, urban farming, and global liberation movements that call for food system change.

\section{Reference}

hooks, b. (2014). Yearning: Race, gender, and cultural politics (2nd ed.). New York: Routledge. 